\title{
Loss of sfrp1 promotes ductal branching in the murine mammary gland
}

\author{
Kelly J Gauger ${ }^{1,2^{*}}$, Akihiko Shimono ${ }^{3}$, Giovanna M Crisi ${ }^{4}$ and Sallie Smith Schneider ${ }^{5,6^{*}}$
}

\begin{abstract}
Background: Secreted frizzled-related proteins (SFRPs) are a family of proteins that block the Wnt signaling pathway and loss of SFRP1 expression is found in breast cancer along with a multitude of other human cancers. Activated Wnt signaling leads to inappropriate mammary gland development and mammary tumorigenesis in mice. When SFRP1 is knocked down in immortalized non-malignant mammary epithelial cells, the cells exhibit a malignant phenotype which resembles the characteristics observed in metastatic breast cancer stem-like cells. However, the effects of SFRP1 loss on mammary gland development in vivo are yet to be elucidated. The work described here was initiated to investigate the role of SFRP1 in mammary gland development and whether $\mathrm{SFRP}^{-/-}$mice exhibit changes in mammary gland morphology and cell signaling pathways shown to be associated with SFRP1 loss in vitro.

Results: 10 week old nulliparous SFRP1 ${ }^{-1-}$ mammary glands exhibited branching with clear lobulo-alveolar development, which normally only occurs in hormonally stimulated mid-pregnant wt mammary glands. Explant cultures of SFRP1 ${ }^{-1-}$ mammary glands display increased levels of a well known Wnt signaling target gene, Axin2. Histomorphologic evaluation of virgin glands revealed that by 10 weeks of age, the duct profile is markedly altered in SFRP1 ${ }^{-1-}$ mice showing a significantly higher density of ducts with distinct alveoli present throughout the mammary gland, and with focal ductal epithelial hyperplasia. These findings persist as the mice age and are evident at 23 weeks of age. Changes in gene expression, including c-Myc, TGF $\beta-2$, Wnt4, RANKL, and Rspo2 early in mammary gland development are consistent with the excessive hyper branching phenotype. Finally, we found that loss of SFRP1 significantly increases the number of mammary epithelial cells capable of mammosphere formation.
\end{abstract}

Conclusions: Our study indicates that SFRP1 gene is critical for maintaining proper mammary gland development, and that reduced levels of SFRP1 results in hyperplastic lesions and its loss may be a critical event in cancer initiation.

Keywords: SFRP1, Mammary gland, Branching morphogenesis

\section{Background}

Members of the Wnt family of secreted proteins play crucial roles in the morphogenesis of most organ systems and regulate cellular proliferation, differentiation, migration and apoptosis [1-3]. The best characterized Wnt pathway is the canonical Wnt/ $\beta$-catenin pathway whereby $\beta$-catenin stimulates the expression of specific target genes including the c-Myc oncogene. Atypical activation of the Wnt/ $\beta$-catenin signaling pathway contributes to

\footnotetext{
*Correspondence: kelly.gauger@baystatehealth.org; sallie.schneider@ baystatehealth.org

${ }^{2}$ Biology Department, University of Massachusetts, Amherst, MA 01003, USA ${ }^{5}$ Veterinary and Animal Sciences, University of Massachusetts, Amherst, MA 01003, USA

Full list of author information is available at the end of the article
}

the genesis of a wide range of human cancers, including breast cancer [3]. In the murine breast, aberrantly activated Wnt signaling leads to inappropriate mammary gland development and mammary tumorigenesis [1].

In addition to embryonic development, Wnt family members are common regulators of postnatal development and of homeostasis in adult tissues, including the growth and differentiation of the mammary gland [4-6]. The first stage of mammary gland development in mice is the specification of mammary rudiments, a prenatal event which occurs around embryonic day 10. The second stage of mammary development begins at around 3 weeks of age at the onset of puberty in response to ovarian hormones, resulting in a rapid expansion of the preexisting rudimentary ductal tree [7]. Branching ductal

\section{Biomed Central}


morphogenesis proceeds across the entire mammary fat pad and is completed at approximately 10 weeks of age. During this phase of development, the growing tips of the ducts form the highly proliferative terminal end buds (TEBs), which house mammary stem cells $[8,9]$. The major changes in morphology and function that are initiated at the start of pregnancy constitute a third stage in mammary gland development that is influenced and regulated by Wnt signaling. Development of the gland at this stage can be reduced to two principal elements: formation of extensive secondary branches of the ductal tree, and the appearance of alveolar units that constitute the secretory apparatus of the gland. Pregnancy dependent hormones normally trigger both of these aspects of mammary morphogenesis, but both can also be induced prematurely by ectopic expression of Wnt proteins in virgin mice [9-12].

Secreted frizzled-related proteins (SFRPs) are a family of Wnt antagonists which contain a cysteine-rich domain that is homologous to the Wnt-binding domain of frizzled receptor proteins [13]. However, SFRPs do not contain a transmembrane domain and therefore are released into the extracellular compartment where they antagonize Wnt signaling by binding to Wnt ligands and preventing ligand-receptor interactions and signal transduction [14]. Loss of SFRP1 expression is found in multiple human cancers including breast cancer [15-17]. When SFRP1 is knocked down in immortalized non-malignant mammary epithelial cells, the cells (TERTsiSFRP1) acquire a malignant phenotype characteristically observed in metastatic breast cancer stem-like cells $[18,19]$. The work described here was initiated to investigate the role of SFRP1 in mammary gland development and whether SFRP1 ${ }^{-1-}$ mice exhibit changes in mammary gland morphology and cell signaling pathways shown to be associated with SFRP1 loss in vitro. Previously, analysis of 41 different non-skeletal tissues, including the mammary gland, in 20 or 40 week old mice has shown no overt morphologic differences between $\mathrm{SFRP}^{+/+}$and SFRP1 ${ }^{-/-}$animals [20]. However, considering that mammary gland development occurs around puberty, we chose to look at the morphological effects of SFRP1 loss beginning at this critical development stage, and at an adult stage. The significance of these studies is considerable because methylation of SFRP1 (resulting in suppression of SFRP1 expression) has been demonstrated to be an early change in premalignant breast lesions [21,22].

\section{Results and discussion}

$\mathrm{SFRP}^{-/-}$mice exhibit precocious mammary gland development

To determine the effect of SFRP1 loss on early mammary gland development, we examined whole mount preparations of mammary glands from female virgin SFRP $1^{+/+}$and SFRP ${ }^{-/-}$mice and compared our findings with pregnant day 8 (P8) and P15 wt animals (Figure 1). Differences in the mammary gland morphology could be detected between SFRP1 ${ }^{+/+}$and SFRP1 ${ }^{-/-}$mice at early stages of puberty. At 5 weeks of age, SFRP1 ${ }^{+/+}$mammary glands exhibited a branching ductal structure typical of a virgin female with very few alveoli growing from terminal branches at the end buds of the ducts (Figure 1A). At higher magnification, the branching ductal structures displayed a smooth surface with a 1-2 cell lining (Figure 1B). In contrast, in 5 weeks old $\mathrm{SFRP}^{-1-}$ animals the mammary gland displayed evidence of nascent ductal side branching (Figure 1C-D), and at 10 weeks of age a significantly more complex arborized ductal network was formed as compared to the age-matched $\mathrm{SFRP}^{+/+}$gland (Figure 1E-H). In addition, SFRP1 ${ }^{-/-}$ mammary glands exhibited branching with clear lobuloalveolar development (low and high magnification images, Figure 1G-H), which normally only occurs in hormonally stimulated mid-pregnant wt mammary glands (Figure 1I-L). Histomorphologic evaluation of virgin glands revealed that at 5 weeks of age, there is only a marginal difference in the number of ducts present in $\mathrm{SFRP}^{-/-}$animals as compared to SFRP1 ${ }^{+/+}$animals (data not shown). By 10 weeks of age the duct profile is markedly altered in SFRP1 ${ }^{-/-}$mice showing a significantly higher density of ducts with distinct alveoli present throughout the mammary gland (Figure 2), and with focal ductal epithelial hyperplasia. This pattern of ductal hyperplasia and precocious alveolar formation that occurs in the 10 week virgin SFRP1 $1^{-1-}$ mammary gland (Figure 2C-D) resembles that of the wt P8 ductal profile (Figure 2I-J). Moreover, these observations persist as the SFRP1 ${ }^{-1-}$ mice age. While alveoli are suitably still absent in 23 week virgin SFRP1 ${ }^{+/+}$animals (Figure 2E$\mathrm{F})$, the presence of precocious alveoli remains and even expands in 23 week virgin SFRP1 $1^{-1-}$ mice (Figure $2 \mathrm{G}-\mathrm{H}$ ), with mammary gland proliferation baring resemblance to wt P15 mice (Figure 2K-L). While mammary glands have previously been examined in SFRP1 ${ }^{+/+}$and SFRP1 $1^{-/-}$ 20 and 40 week old animals [20], the methodology of mammary gland analysis we employed revealed that there is a striking difference in morphology between geneotypes. Our findings of precocious development and persistent hyperplasia of ducts/lobulo-alveolar units in SFRP1 $1^{-/-}$mice are significant because they suggest that loss of SFRP1 may contribute to an increase in breast tumor susceptibility.

Our results are consistent with previous studies showing that upregulation of the $\mathrm{Wnt} / \beta$-catenin pathway and activation of $\beta$-catenin in mice induces precocious lobulo-alveolar hyperplasia [10-12]. In particular, Lane et. al. demonstrated that mammary glands from Wnt- 


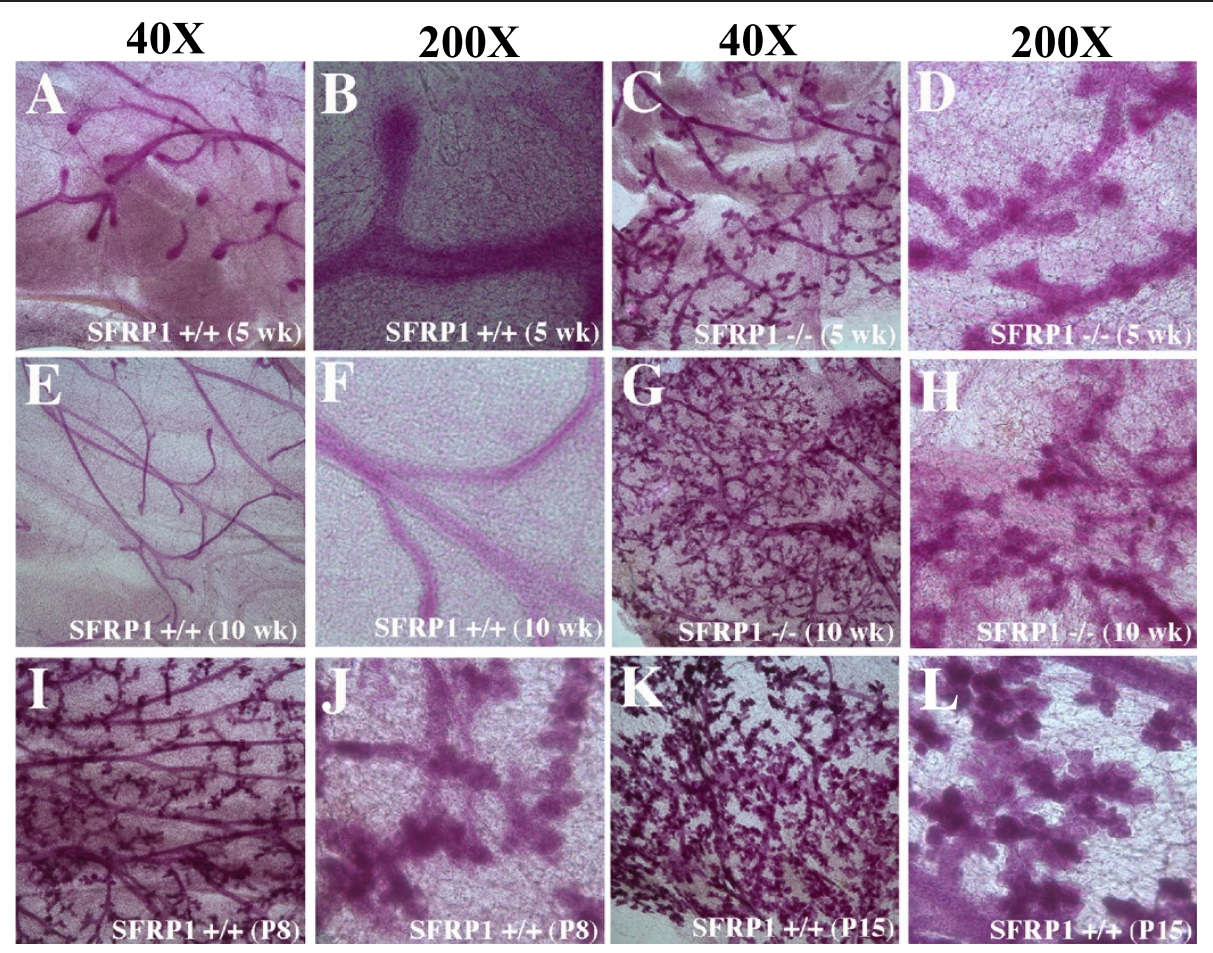

Figure 1 Comparison of the morphology of 5 wk virgin, 10 wk virgin, pregnant day 8, and pregnant day 15 mammary glands. Whole mounts of inguinal mammary glands stained with carmine alum from (A-B) 5 wk SFRP1 ${ }^{+/+}$, (C-D) $5 \mathrm{wk} \mathrm{SFRP1} 1^{-/}$, (E-F) 10 wk SFRP1 ${ }^{+/+}$, (G-H) 10 wk SFRP1 ${ }^{-1-}$, (I-J) wt P8, and (K-L) wt P15 females. (B,D,F, H,J, L) Shown medium magnification (200X) of selection from adjacent low magnification left panel (40X). Tissue was harvested from and assessed in 6 animals/genotype.

$10 \mathrm{~b}$ virgin mice are more branched and have a higher density of ducts compared to non-transgenic littermates [11]. This pattern of ductal hyperplasia and precocious alveolar formation has also been described in MMTVWnt1 mice [9,23]. Moreover, Bradbury et. al. showed that constitutive expression of Wnt4 in the virgin mammary gland also induces structures with a morphology similar to that seen in pregnancy [24]. To determine whether the mammary glands of SFRP1 ${ }^{-1-}$ mice have more responsive $\mathrm{Wnt} / \mathrm{\beta}$-catenin signaling, we exploited an ex vivo tissue culture assay to survey the expression of a well known Wnt/ $\beta$-catenin target gene, Axin2, in response to Wnt3a. As shown in Figure 3, both in the absence and presence of the Wnt3a $\beta$-catenin stimulating ligand, SFRP1 ${ }^{-1-}$ mice express higher levels of Axin2 protein (Figure $3 \mathrm{~B} \& D$ ). Taken together, our results suggest that SFRP1 is an essential regulator of normal mammary gland development and likely functions in part by antagonizing the $\mathrm{Wnt} / \beta$-catenin signaling pathway.

\section{Genes involved in mammary gland morphogenesis are overexpressed early in $\mathrm{SFRP} 1^{-/-}$mice}

We next sought to determine whether there were changes in gene expression early in development that might help explain the excessive hyper branching phenotype observed in 10 week old SFRP1 ${ }^{-/-}$mice. c-Myc is a well characterized downstream gene of $\mathrm{Wnt} / \beta$-catenin signaling that is upregulated in response to $\beta$-catenin transcriptional activation. Real-time PCR studies confirmed that c-Myc mRNA levels were significantly higher in the mammary gland of SFRP1 ${ }^{-1}$ mice (Figure 4A). Interestingly c-Myc has been shown to induce precocious mammary development and transformation when overexpressed in the mouse mammary gland $[25,26]$. In addition, virgin mice overexpressing constitutively active $\beta$-catenin express abnormally high levels of c-Myc mRNA [10].

Transforming growth factor (TGF)- $\beta$ is a multifunctional cytokine that regulates a variety of physiological processes and also plays a dual role during mammary gland development and tumorigenesis. We have shown that loss of SFRP1 expression in vitro allows mammary cells to acquire sensitivity to TGF- $\beta$ signaling [27]. In an initial screen of genes affected by SFRP1 loss in HMECs we identified several upregulated genes within the TGF$\beta$ pathway, including the TGF- $\beta 2$ ligand [27]. The realtime PCR data presented here demonstrate that SFRP1 loss in vivo also results in significantly increased mRNA levels of TGF- $\beta 2$ (Figure 4B). These findings may in part explain the altered mammary gland 


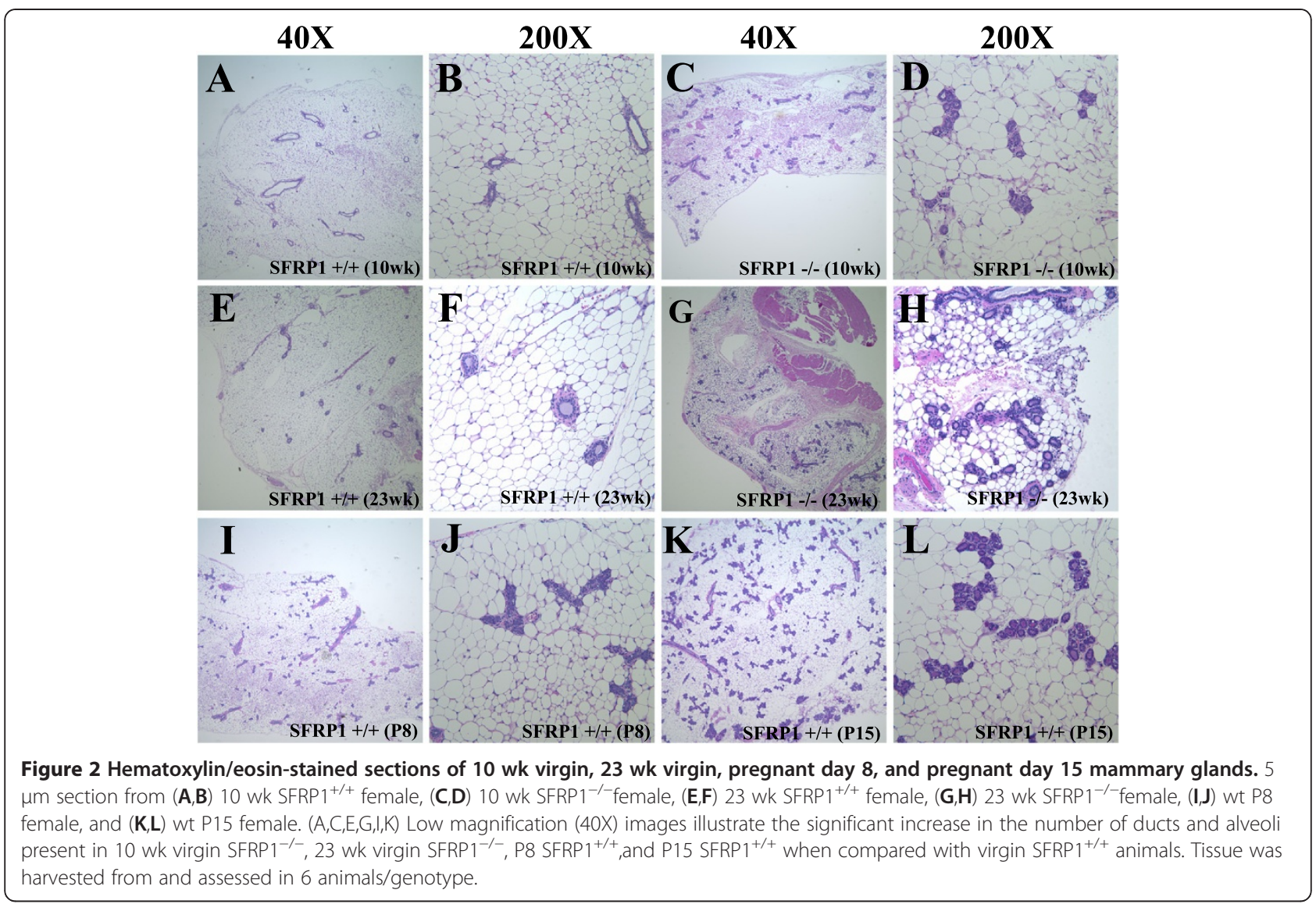

morphogenesis observed in SFRP1 $1^{-/}$mice. Specifically, it has been shown that TGF- $\beta 2$, but not TGF- $\beta 1$ or TGF- $\beta 3$, is critical for lung branching in vivo [28] and synergizes with Wnt to promote mammary gland branching in vitro [29].

As discussed previously, overexpression of Wnt1, Wnt10b, and/or Wnt4 induces mammary gland hyper branching. Therefore, we wanted to establish whether these particular Wnt ligands are upregulated in SFRP1 $1^{-/}$ animals. The expression of Wnt1 and Wnt10b was unaffected by SFRP1 loss (data not shown), however Wnt4 mRNA levels were significantly elevated in the mammary gland of SFRP1 ${ }^{-/-}$mice (Figure 4C). Interestingly, Wnt4 is expressed during the period when sidebranching occurs in early to mid-pregnancy [30,31]. Brisken et. al. showed that Wnt4 null mammary glands were deficient in early lobulo-alveolar mammary outgrowth during pregnancy, and that Wnt4 is an effector for progesterone-induced mammary growth [32].

Critical to the Wnt4 downstream signaling for branching morphogenesis is the receptor of activated NF- $\mathrm{KB}$ ligand (RANKL) $[33,34]$. RANKL was originally characterized for its role in the development, survival, and activation of osteoclasts during bone remodeling [33].
Subsequent studies have shown that RANKL deficient mice exhibit a significant decrease in parity-induced mammary alveologenesis which results in a lactational defect [34]. Furthermore, transgenic overexpression of RANKL or RANK (RANKL receptor) alone into the murine mammary gland elicits ductal side branching, alveologenesis, and mammary hyperplasia $[35,36]$. Considering that SFRP1 has been shown to bind to and inhibit RANKL mediated action [37], we sought to determine whether the expression of RANKL is affected by SFRP1 loss. Indeed, we found that mRNA levels of RANKL were significantly elevated in the mammary gland of SFRP1 ${ }^{-l-}$ mice (Figure 4D). These data lend support to the notion that SFRP1 may play a role in tumor susceptibility since abrogation or accentuation of RANKL signaling renders the mammary epithelium markedly resistant or susceptible to mammary tumorigenesis respectively [36,38]. Since RANKL has a role in bone remodeling and loss of SFRP1 increases the thickness of the trabecular bones [20], it has been suggested that SFRP1 inhibitors may be beneficial for the treatment and/or prevention of osteoporosis. However, SFRP1 inhibitors may not be beneficial to women who are genetically predisposed or who have pre-malignant 


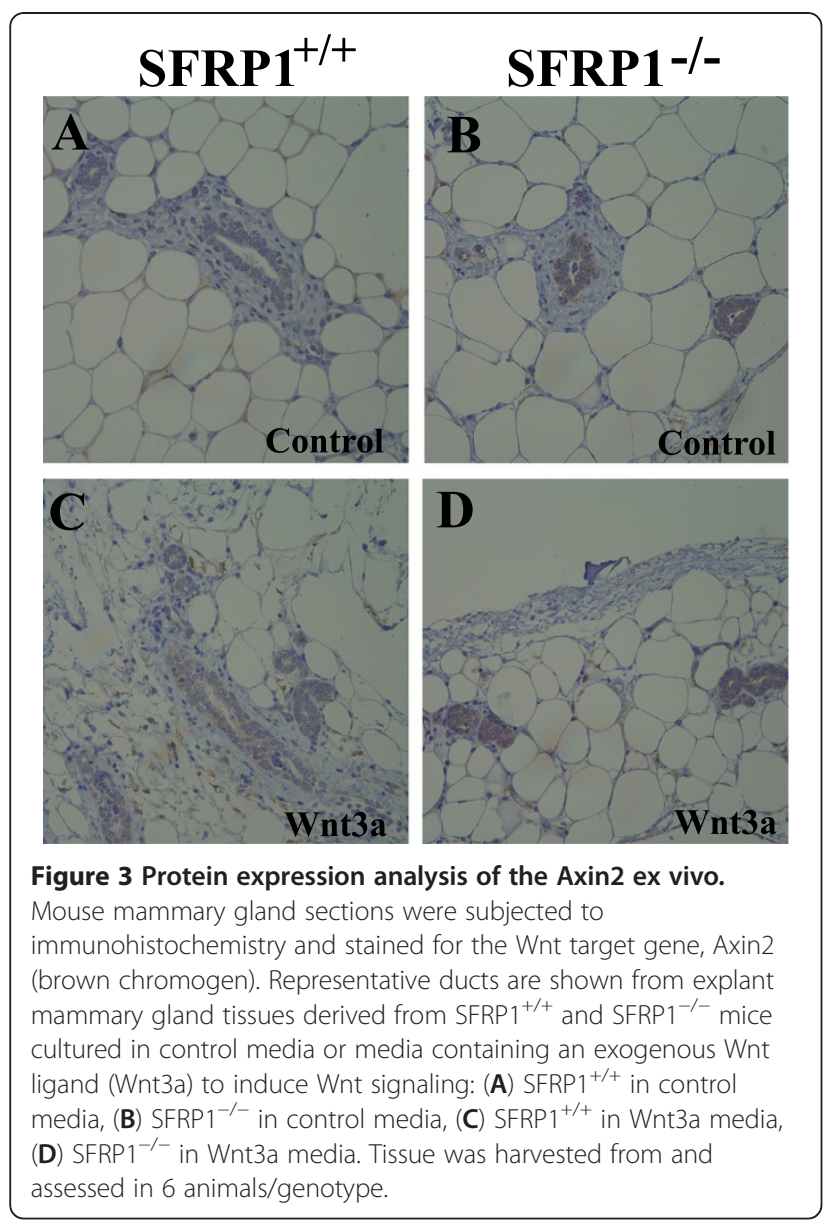

lesions and may put them at risk for developing breast cancer.

R-spondin (RSPO) family proteins activate the canonical WNT signaling pathway by binding to the Wnt co-receptor LRP6 leading to $\beta$-catenin-dependent gene activation [39-41]. Interestingly, the expression of Rspo2 and other Rspo family members is induced when mouse mammary tumor virus (MMTV) is inserted into mammary epithelial cells, and these proteins have been associated with malignant transformation and tumorigenesis [42-44]. Loss of Rspo1 hinders the development of the murine mammary gland leading to lack of side branching along secondary ducts [45]. At 5 weeks of age in SFRP1 $1^{-/}$ mice, we started observing changes in the expression of genes involved in branching morphogenesis. Although we did not see Rspol changes at this stage (Figure 4E), the expression of Rspo2 is significantly elevated (Figure 4F). Additionally enhanced side branching at 10 wks of age in response to SFRP1 loss is associated with significantly elevated expression of both Rspo1 and Rspo2 (data not shown). These findings may partially explain how SFRP1 loss increases the expression of Wnt4, through Rspo2 enhancement of the $\beta$-catenin-dependent activity of Wnt4 in murine epithelial cells [46]. Furthermore, the expression pattern of Rspo1 parallels that of Wnt4 during mammary gland development which indicates that there is functional relationship between these Wnt signaling proteins [45].

\section{Mammary epithelial cells derived from SFRP $1^{-/-}$mice have more mammosphere initiating cells}

Ductal outgrowth is driven by TEBs, which are believed to house a small population of cells that are essential for mammary gland development, mammary stem cells (MaSCs) $[8,9]$. Importantly, MaSCs are capable of regenerating all cell-lineages that comprise the murine mammary gland and support for their existence comes from cell enrichment studies using specific cell surface markers as well as mammary gland transplantation experiments [47,48]. Similar to stem cells in either the hematopoietic system or neuronal system, the selfrenewal and differentiation of $\mathrm{MaSCs}$ is regulated by multiple genes and pathways. Several studies have shown that Wnt/ $\beta$-catenin signaling is activated in several stem cell types, including in mammary stem cells. Liu et. al. demonstrated that transgenic mice with activated Wnt/ $\beta$-catenin signaling in the mammary gland have a significantly higher stem cell-enriched population compared to wild type mice [49]. Additionally, the stem cell-enriched population of cultured primary mammary epithelial cells was significantly increased when cells were treated with a Wnt agonist and this effect could be abrogated by the addition of a Wnt pathway inhibitor [49].

Stem cells and progenitor cells from the human mammary gland are able to grow in an anchorage independent manner (constituting mammospheres) and have been shown to express very low levels of SFRP1 [50]. Interestingly, the expression of SFRP1 is up-regulated when mammospheres are induced to differentiate [50]. Considering the premature branching that occurs in the $\mathrm{SFRP}^{-1-}$ murine mammary gland and that SFRP1 is a Wnt signaling antagonist, mammosphere formation capacity was compared between mammary epithelial cells derived from SFRP1 $1^{+/+}$and SFRP1 $1^{-/-}$animals. We found that loss of SFRP1 significantly increases the number of mammary epithelial cells capable of mammosphere formation (Figure 5). These data are fully consistent with previous studies showing that inhibition of SFRP1 increases mammosphere formation [18,19]. Although mammosphere formation is not a definitive measure of the stem cell population, the literature has shown that such a capacity is constantly associated with resolute in vivo stem cell measures [51-53]. If SFRP1 loss indeed enhances stem cell number, the increase in mammosphere formation is of importance because stem cells are thought to play a key role in malignant transformation of the breast since they are more likely to accumulate 

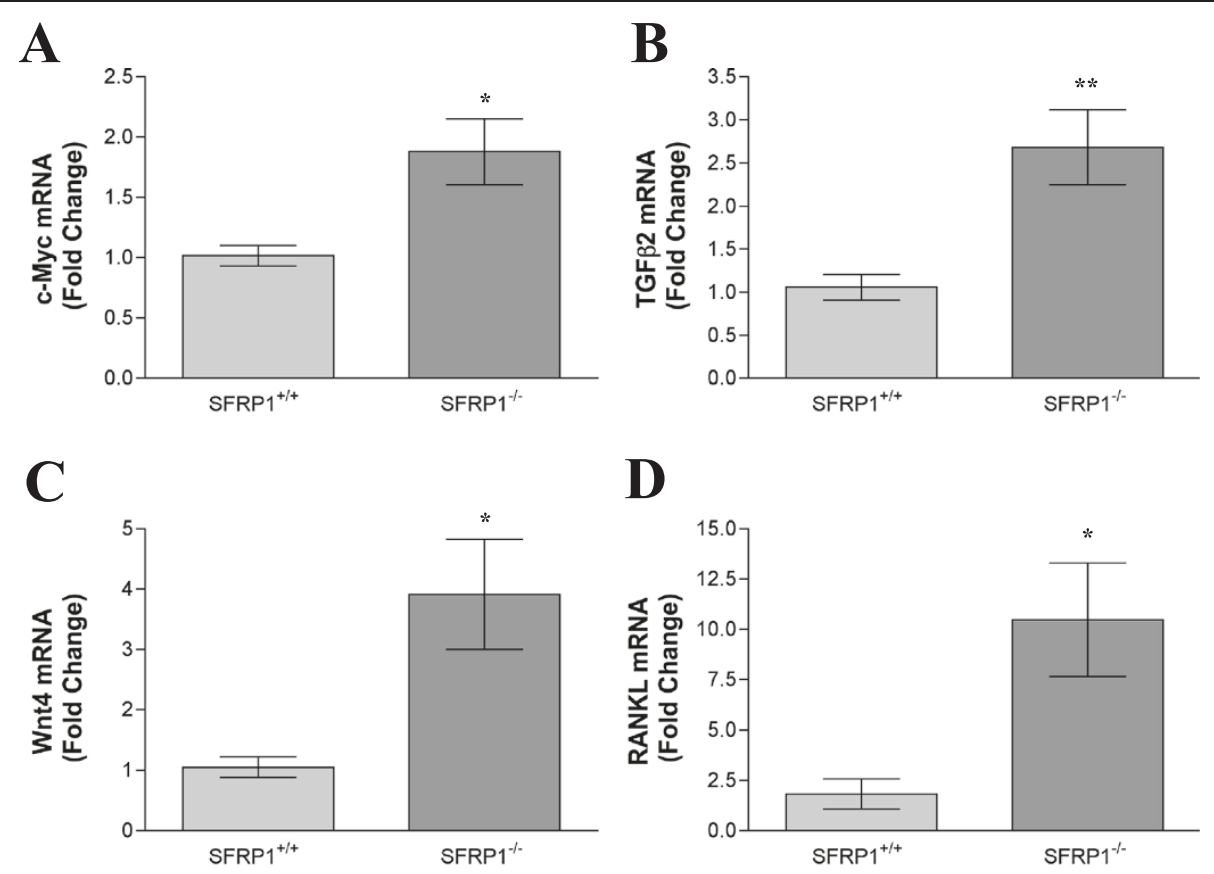

D
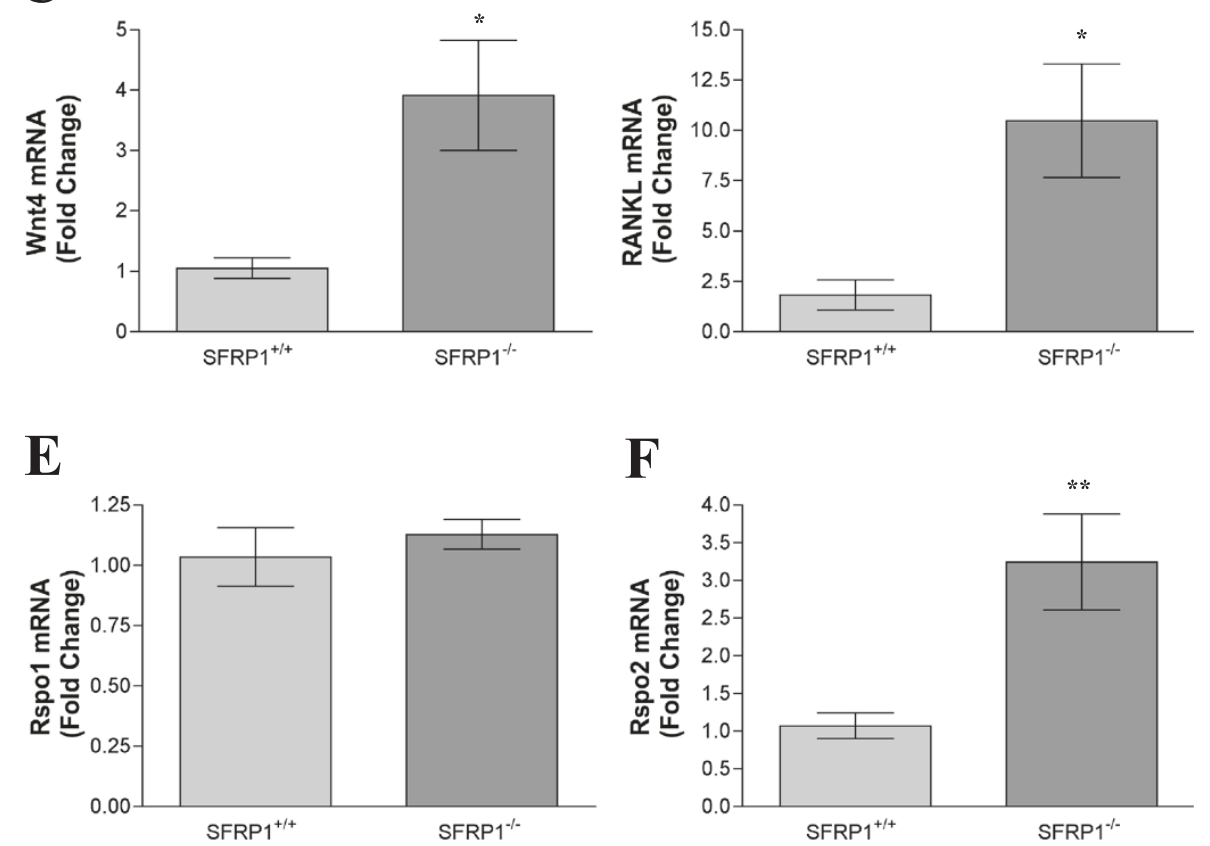

Figure 4 Expression analysis of genes altered in SFRP1 ${ }^{-1-}$ animals that may be involved in mammary gland branching. For real-time PCR analysis of c-Myc, TGF- $\beta 2$, Wnt4, RANKL, Rspo1, and Rspo2 gene expression, total RNA was isolated from the mammary glands of 5 wk virgin $\mathrm{SFRP}^{+/+}$and SFRP ${ }^{-/-}$females ( $n=6$ animals/genotype). Real-time PCR experiments were carried out in duplicate. The results shown represent experiments performed in duplicate and normalized to the amplification of $\beta$-actin mRNA. Bars represent mean \pm SEM of the fold change with respect to vehicle treated cells. ${ }^{*} p<0.05,{ }^{* *} p<0.01$ (significantly different from vehicle treated cells using student's $t$-test).

mutations and pass them to progeny during their longlife span $[54,55]$. Therefore the potential effect of SFRP1 loss on stem cell number and mammosphere formation is critical to breast tumorigenesis.

\section{Conclusions}

The work described herein clearly demonstrate that $\mathrm{SFRP}^{-1-}$ mice exhibit precocious mammary gland side branching with clear lobulo-alveolar development, which normally only occurs in hormonally stimulated midpregnant wt mammary glands. These changes may be partially explained by alterations in the expression of genes critical for mammary gland development and by an increase in the number of mammosphere forming cells. Previously, it has been demonstrated that suppression of SFRP1 expression is an early change in human premalignant breast lesions [21]. Taken together, our study indicates that the SFRP1 gene is critical for maintaining proper mammary gland development, that reduced levels of SFRP1 results in hyperplastic lesions, and its loss may be a critical event in cancer initiation. Therefore, caution should be exercised in the potential use of SFRP1 inhibitors for the treatment of osteroporosis until the effects of such inhibition on breast tumorigenesis are fully elucidated.

\section{Methods}

Animals

All procedures were performed in accordance with the $\mathrm{NIH}$ guidelines for the ethical treatment of animals and 


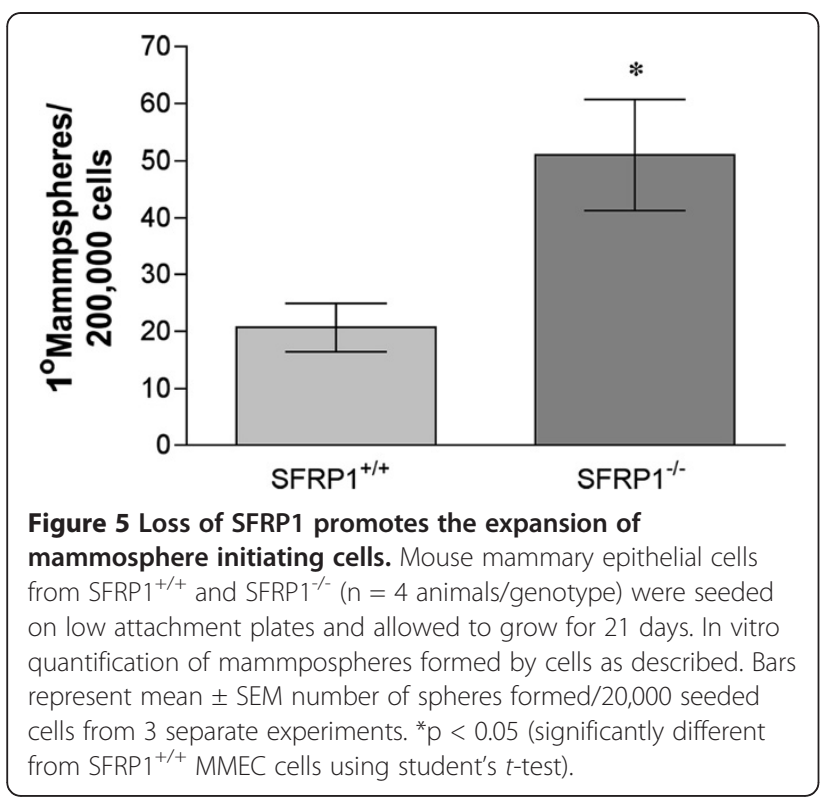

were approved by the Baystate Medical Center Institutional AnimalCare and Use Committee before initiating these studies. Female 129/C57Blk6 mice $(n=6)$ were individually housed in plastic cages with food and water provided continuously, and maintained on a 12:12 light cycle.

\section{Whole-mounts and carmine stain of mammary glands}

Mice were euthanized with carbon dioxide and fifth inguinal mammary glands were excised from $5 \mathrm{wk}$ virgin, 10 wk virgin, pregnant day 8 , and pregnant day 15 animals, spread on microscope slides, and fixed overnight in methacarn (60\% methanol, 30\% chloroform, $10 \%$ acetic acid). The fixed glands were washed in 70\% ethanol for $15 \mathrm{~min}$, rinsed in water for $5 \mathrm{~min}$, and stained overnight at $4^{\circ} \mathrm{C}$ in carmine alum stain (1 g carmine and $2.5 \mathrm{~g}$ aluminum potassium sulfate in $500 \mathrm{ml}$ water). The glands were then dehydrated progressively in 70\%-95\%-100\% ethanol, cleared in xylene for $1 \mathrm{hr}$, and mounted on slides with Cytoseal $^{\mathrm{m}} \mathrm{XYL}$ mounting medium (Richard-Allan Scientific). Mammary whole mounts where photographed using an Olympus BX41 light microscope using SPOTSOFTWARE (Diagnostic Instruments, Inc, Sterling Heights, MI).

\section{Histomorphology}

Fourth or sixth inguinal mammary glands from 5 wk virgin, $10 \mathrm{wk}$ virgin, $23 \mathrm{wk}$ virgin, pregnant day 8 , and pregnant day 15 animals ( $\mathrm{n}=6$ animals/genotype) were formalin-fixed and paraffin-embedded. Tissue sections were cut on a Leica microtome at a thickness of $4 \mu \mathrm{m}$ on Superfrost-plus slides, and stained with hematoxylin and eosin (H\&E) per standard protocol. Briefly, slides were dried in a microwave for $1 \mathrm{~min}$ and then at $62^{\circ} \mathrm{C}$ for 15 minutes. Slides were subsequently de-paraffinized with xylene 3X, cleared with graded ETOH $(100 \%$ X2, $95 \%, 70 \%)$, and rinsed in $\mathrm{dH}_{2} \mathrm{O}$. Sections were stained for 3 minutes in Mayer's hematoxylin, washed with glacial acetic acid water for $15 \mathrm{sec}$, and then ammonia water to blue, and stained with eosin. Finally, slides were dehydrated in ETOH and xylene before manual coverslipping. Stained images were captured with an Olympus BX41 light microscope using SPOTSOFTWARE.

\section{Ex vivo tissue culture and immunohistochemistry}

Mice were euthanized with carbon dioxide and fourth inguinal mammary glands were excised $(n=6$ animals/ genotype). The tissue was aseptically minced and for each genotype, a representation from all 6 animals was placed on 2 different Surgifoam gelatin sponges (Ferrosan, Sueborg, Denmark) in $60 \mathrm{~mm}$ tissue culture dishes containing $5 \mathrm{~mL}$ of control or Wnt3a medium prepared as described [18]. Explant cultures were maintained for 24 hours in $5 \% \mathrm{CO}_{2}$ air and subsequently formalin-fixed and paraffin-embedded.

Immunohistochemistry (IHC) was performed on a DakoCytomation autostainer using the Envision HRP Detection system (Dako, Carpinteria, CA). Each mammary tissue block was sectioned at $4 \mu \mathrm{m}$ on a graded slide, deparaffinized in xylene, rehydrated in graded ethanols, and rinsed in Tris-phosphate-buffered saline (TBS). Heat induced antigen retrieval was performed in a microwave at $98^{\circ} \mathrm{C}$ in $0.01 \mathrm{M}$ citrate buffer. After cooling for 20 minutes, sections were rinsed in TBS and subjected to the primary rabbit polyclonal anti-Axin2 antibody (1:100, Abcam, ab32197) for 45 minutes. Immunoreactivity was visualized by incubation with chromogen diaminobenzidine (DAB) for 5 minutes. Tissue sections were counterstained with hematoxylin, dehydrated through graded ethanols and xylene, and cover-slipped. Images were captured with an Olympus BX41 light microscope using SPOTSOFTWARE.

\section{RNA isolation and real-time PCR analysis}

Total RNA was extracted from the sixth inguinal mammary glands of 5 week old animals using an acid-phenol extraction procedure [56], according to the manufacturer's instructions (Trizol, Invitrogen, Carlsbad, CA). Relative levels of the mRNA expression of target genes was determined by quantitative real-time PCR using the M3005 $\mathrm{P}^{\mathrm{ma}}$ real-time PCR system (Stratagene, La Jolla, CA) and all values were normalized to the amplification of $\beta$-Actin. The PCR primer sequences are described in Table 1. The assays were performed using the 1-Step Brilliant $^{\circledR}$ SYBRII ${ }^{\circledR}$ Green QRT-PCR Master Mix Kit (Stratagene) containing $200 \mathrm{nM}$ forward primer, $200 \mathrm{nM}$ reverse primer, and $100 \mathrm{ng}$ total RNA. The conditions for cDNA synthesis and target mRNA amplification were performed as follows: 1 cycle of $50^{\circ} \mathrm{C}$ for $30 \mathrm{~min} ; 1$ 


\section{Table 1 PCR primer sequences}

\begin{tabular}{|c|c|c|}
\hline \multirow[t]{2}{*}{ cMyc } & forward & 5'-CAGCGACTCTGAAGAAGAGC-3' \\
\hline & reverse & 5'-GTTGTGCTGGTGAGTGGAGA-3' \\
\hline \multirow[t]{2}{*}{ Wnt-4 } & forward & 5'-ATGCCCTTGTCACTGCAAA-3' \\
\hline & reverse & 5'-CTGGACTCCCTCCCTGTCTT-3' \\
\hline \multirow[t]{2}{*}{ TGF- $\beta 2$} & forward & 5'-AAGCTTCGGGATTTATGGTG-3' \\
\hline & reverse & 5'-TGGAGTTCAGACACTCAAA-3' \\
\hline \multirow[t]{2}{*}{ RANKL } & forward & 5'-TGAAGACACACTACCTGACTCCTG-3' \\
\hline & reverse & 5'-CCACAATGTGTTGCAGTTCC-3' \\
\hline \multirow[t]{2}{*}{ Rspo1 } & forward & 5'- CGACATGAACAAATGCATCA -3' \\
\hline & reverse & 5'- CTCCTGACACTTGGTGCAGA -3' \\
\hline \multirow[t]{2}{*}{ Rspo2 } & forward & 5'- GCCCATCAGGGTATTATGGA -3' \\
\hline & reverse & 5'- TCACAGTTTTCTATTCTGCATCG -3' \\
\hline \multirow[t]{2}{*}{$\beta$-Actin } & forward & 5'- CTAAGGCCAACCGTGAAAAG -3' \\
\hline & reverse & $5^{\prime}-$ ACCAGAGGCATACAGGGACA -3' \\
\hline
\end{tabular}

cycle of $95^{\circ} \mathrm{C}$ for $10 \mathrm{~min}$; and 35 cycles each of $95^{\circ} \mathrm{C}$ for $30 \mathrm{~s}, 55^{\circ} \mathrm{C}$ for $1 \mathrm{~min}$, and $72^{\circ} \mathrm{C}$ for $30 \mathrm{~s}$.

\section{Primary mouse mammary cell isolation and mammosphere culture}

Eight $8-10$ week old virgin mice were euthanized with carbon dioxide (4. SFRP1 ${ }^{+/+}$and $4 \mathrm{SFRP}^{-/-}$) and fourth mammary glands were harvested, minced, and finally dissociated in DMEM:F12 (Sigma, St. Louis, MO) supplemented with $5 \%$ fetal bovine serum (Gibco, Paisleley, UK), $2 \mathrm{mg} / \mathrm{ml}$ collagenase (Worthington Biochemicals, Freehold, NJ), 100u/ml hyaluronidase (Sigma), 100u/ml pen/strep (Gibco) and $100 \mu \mathrm{g} / \mathrm{ml}$ gentamicin (Gibco) for 6 hours. The cell pellet was collected and further dissociated with $1 \mathrm{mlpre-warmed} \quad 0.05 \%$ Trypsin-EDTA (Gibco) and $200 \mu 11 \mathrm{mg} / \mathrm{ml}$ Dnase I (Roche, Mannheim, Germany). Cell suspensions were sieved through a $40 \mu \mathrm{m}$ cell strainer to obtain single cell suspensions. Primary single cells were seeded onto ultra-low attachment dishes (Corning, Corning, NY) at a density of 20,000 viable cells $/ \mathrm{ml}$. Cells were grown in a serum-free mammary growth medium (EpiCult ${ }^{\circledR B}$ for Mouse Mammary Epithelial Cell Culture, Vancouver, BC) supplemented with 10ng/ml EGF (Sigma), $10 \mathrm{ng} / \mathrm{ml}$ FGF (Sigma), $4 \mu \mathrm{g} / \mathrm{ml}$ heparin, $100 \mathrm{u} / \mathrm{ml}$ pen/strep (Gibco) and $100 \mu \mathrm{g} / \mathrm{ml}$ gentamicin (Gibco) [50]. On day 21, the total number of mammospheres was quantified by counting spheres that were at least $100 \mu \mathrm{m}$ in size. Images of mammosphere formation were captured with a Nikon Eclipse TE2000-Uusing Metaview ${ }^{\text {mit }}$ software.

\section{Abbreviations}

SFRP1: secreted frizzled related protein; TEB: terminal end buds; TGF- $\beta$ : transforming growth factor- $\beta$; RANKL: receptor of activated NF-KB ligand; MaSC: mammary stem cell.

\section{Competing interests}

The authors do not have any financial or personal relationships with other people or organizations that could inappropriately influence the work described in this manuscript.

\section{Authors' contributions}

KG drafted the manuscript and performed all of the described experiments. AS provided our laboratory with the SFRP ${ }^{-1-}$ mice. GC evaluated and assisted in the interpretation of stained tissue slides, and edited the manuscript. SS participated in the study design, edited the manuscript, and gave final approval of the version to be published. All authors read and approved the final manuscript.

\section{Acknowledgements}

This work was funded by a grant from the Rays of Hope Foundation.

\section{Author details}

${ }^{1}$ Pioneer Valley Life Sciences Institute, Baystate Medical Center, Springfield, MA 01199 , USA. ${ }^{2}$ Biology Department, University of Massachusetts, Amherst, MA 01003, USA. ${ }^{3}$ TransGenic Inc, Chuo, Kobe 650-0047, Japan. ${ }^{4}$ Department of Pathology, Baystate Medical Center, Springfield, MA 01199, USA. ${ }^{5}$ Veterinary and Animal Sciences, University of Massachusetts, Amherst, MA 01003, USA. ${ }^{6}$ Pioneer Valley Life Sciences Institute, 3601 Main St, Springfield, MA 01199, USA

Received: 28 February 2012 Accepted: 13 August 2012 Published: 28 August 2012

\section{References}

1. Brennan KR, Brown AM: Wnt proteins in mammary development and cancer. J Mammary Gland Biol Neoplasia 2004, 9:119-131.

2. Karim R, Tse G, Putti T, Scolyer R, Lee S: The significance of the Wnt pathway in the pathology of human cancers. Pathology 2004, 36:120-128.

3. Polakis P: Wnt signaling and cancer. Genes Dev 2000, 14:1837-1851.

4. Hatsell S, Rowlands T, Hiremath M, Cowin P: Beta-catenin and Tcfs in mammary development and cancer. J Mammary Gland Biol Neoplasia 2003, 8:145-158

5. Howe LR, Brown AM: Wnt signaling and breast cancer. Cancer Biol Ther 2004, 3:36-41.

6. Smalley MJ, Dale TC: Wnt signaling and mammary tumorigenesis. J Mammary Gland Biol Neoplasia 2001, 6:37-52.

7. Daniel CW, Silberstein GB: Postnatal development of the rodent mammary gland. In The mammary gland. Edited by Neville MC, Daniel CW. New York: Plenum Press; 1987:3-36.

8. Smalley M, Ashworth A: Stem cells and breast cancer: A field in transit. Nat Rev Cancer 2003, 3:832-844.

9. Tsukamoto AS, Grosschedl R, Guzman RC, Parslow T, Varmus HE: Expression of the int- 1 gene in transgenic mice is associated with mammary gland hyperplasia and adenocarcinomas in male and female mice. Cell 1988, 55:619-625.

10. Imbert A, Eelkema $\mathrm{R}$, Jordan $\mathrm{S}$, Feiner $\mathrm{H}$, Cowin P: Delta N89 beta-catenin induces precocious development, differentiation, and neoplasia in mammary gland. J Cell Biol 2001, 153:555-568.

11. Lane TF, Leder P: Wnt-10b directs hypermorphic development and transformation in mammary glands of male and female mice. Oncogene 1997, 15:2133-2144.

12. Michaelson JS, Leder P: beta-catenin is a downstream effector of Wntmediated tumorigenesis in the mammary gland. Oncogene 2001, 20:5093-5099.

13. Finch PW, He X, Kelley MJ, Uren A, Schaudies RP, Popescu NC, Rudikoff S, Aaronson SA, Varmus HE, Rubin JS: Purification and molecular cloning of a secreted, Frizzled-related antagonist of Wnt action. Proc Natl Acad Sci U S A 1997, 94:6770-6775.

14. Bafico A, Gazit A, Pramila T, Finch PW, Yaniv A, Aaronson SA: Interaction of frizzled related protein (FRP) with Wnt ligands and the frizzled receptor suggests alternative mechanisms for FRP inhibition of Wnt signaling. J Biol Chem 1999, 274:16180-16187.

15. Klopocki E, Kristiansen G, Wild PJ, Klaman I, Castanos-Velez E, Singer G, Stohr $R$, Simon R, Sauter G, Leibiger H, et al: Loss of SFRP1 is associated with breast cancer progression and poor prognosis in early stage tumors. Int $J$ Oncol 2004, 25:641-649. 
16. Wong SC, Lo SF, Lee KC, Yam JW, Chan JK, Hsiao WWL: Expression of frizzled-related protein and Wnt-signalling molecules in invasive human breast tumours. J Pathol 2002, 196:145-153.

17. Zhou Z, Wang J, Han X, Zhou J, Linder S: Up-regulation of human secreted frizzled homolog in apoptosis and its down-regulation in breast tumors. Int J Cancer 1998, 78:95-99.

18. Gauger KJ, Hugh JM, Troester MA, Schneider SS: Down-regulation of sfrp1 in a mammary epithelial cell line promotes the development of a cd44high/cd24low population which is invasive and resistant to anoikis Cancer Cell Int 2009, 9:11.

19. Scheel C, Eaton EN, Li SH, Chaffer CL, Reinhardt F, Kah KJ, Bell G, Guo W, Rubin J, Richardson AL, Weinberg RA: Paracrine and autocrine signals induce and maintain mesenchymal and stem cell states in the breast. Cell 2011, 145:926-940.

20. Bodine PV, Zhao W, Kharode YP, Bex FJ, Lambert AJ, Goad MB, Gaur T, Stein GS, Lian JB, Komm BS: The Wnt antagonist secreted frizzled-related protein-1 is a negative regulator of trabecular bone formation in adult mice. Mol Endocrinol 2004, 18:1222-1237.

21. Dumont N, Crawford YG, Sigaroudinia M, Nagrani SS, Wilson MB, Buehring GC, Turashvili G, Aparicio S, Gauthier ML, Fordyce CA, et al: Human mammary cancer progression model recapitulates methylation events associated with breast premalignancy. Breast Cancer Res 2009, 11:R87.

22. Browne EP, Punska EC, Lenington S, Otis CN, Anderton DL, Arcaro KF: Increased promoter methylation in exfoliated breast epithelial cells in women with a previous breast biopsy. Epigenetics 2011, 6:1425-1435.

23. Edwards PA, Hiby SE, Papkoff J, Bradbury JM: Hyperplasia of mouse mammary epithelium induced by expression of the Wnt-1 (int-1) oncogene in reconstituted mammary gland. Oncogene 1992, 7:2041-2051.

24. Bradbury JM, Edwards PA, Niemeyer CC, Dale TC: Wnt-4 expression induces a pregnancy-like growth pattern in reconstituted mammary glands in virgin mice. Dev Biol 1995, 170:553-563.

25. He TC, Sparks AB, Rago C, Hermeking H, Zawel L, da Costa LT, Morin PJ, Vogelstein B, Kinzler KW: Identification of c-MYC as a target of the APC pathway. Science 1998, 281:1509-1512.

26. Sinn E, Muller W, Pattengale P, Tepler I, Wallace R, Leder P: Coexpression of MMTV/v-Ha-ras and MMTV/c-myc genes in transgenic mice: synergistic action of oncogenes in vivo. Cell 1987, 49:465-475.

27. Gauger KJ, Chenausky KL, Murray ME, Schneider SS: SFRP1 reduction results in an increased sensitivity to TGF-beta signaling. BMC Cancer 2011 11:59.

28. Liu J, Tseu I, Wang J, Tanswell K, Post M: Transforming growth factor beta2, but not beta1 and beta3, is critical for early rat lung branching. Dev Dyn 2000, 217:343-360.

29. Uyttendaele H, Soriano JV, Montesano R, Kitajewski J: Notch4 and Wnt-1 proteins function to regulate branching morphogenesis of mammary epithelial cells in an opposing fashion. Dev Biol 1998, 196:204-217.

30. Gavin BJ, McMahon AP: Differential regulation of the Wnt gene family during pregnancy and lactation suggests a role in postnatal development of the mammary gland. Mol Cell Biol 1992, 12:2418-2423.

31. Weber-Hall SJ, Phippard DJ, Niemeyer CC, Dale TC: Developmental and hormonal regulation of Wnt gene expression in the mouse mammary gland. Differentiation 1994, 57:205-214.

32. Brisken C, Heineman A, Chavarria T, Elenbaas B, Tan J, Dey SK, McMahon JA, McMahon AP, Weinberg RA: Essential function of Wnt-4 in mammary gland development downstream of progesterone signaling. Genes Dev 2000, 14:650-654

33. Suda T, Takahashi N, Udagawa N, Jimi E, Gillespie MT, Martin TJ: Modulation of osteoclast differentiation and function by the new members of the tumor necrosis factor receptor and ligand families. Endocr Rev 1999, 20:345-357.

34. Fata JE, Kong YY, Li J, Sasaki T, Irie-Sasaki J, Moorehead RA, Elliott R, Scully S, Voura EB, Lacey DL, et al: The osteoclast differentiation factor osteoprotegerin-ligand is essential for mammary gland development. Cell 2000, 103:41-50.

35. Fernandez-Valdivia R, Mukherjee A, Ying Y, Li J, Paquet M, DeMayo FJ, Lydon JP: The RANKL signaling axis is sufficient to elicit ductal sidebranching and alveologenesis in the mammary gland of the virgin mouse. Dev Biol 2009, 328:127-139.

36. Gonzalez-Suarez E, Jacob AP, Jones J, Miller R, Roudier-Meyer MP, Erwert R, Pinkas J, Branstetter D, Dougall WC: RANK ligand mediates progestin- induced mammary epithelial proliferation and carcinogenesis. Nature 2011, 468:103-107.

37. Hausler KD, Horwood NJ, Chuman Y, Fisher JL, Ellis J, Martin TJ, Rubin JS Gillespie MT: Secreted frizzled-related protein-1 inhibits RANKLdependent osteoclast formation. J Bone Miner Res 2004, 19:1873-1881.

38. Schramek D, Sigl V, Penninger JM: RANKL and RANK in sex hormoneinduced breast cancer and breast cancer metastasis. Trends Endocrinol Metab 2011, 22:188-194.

39. Kazanskaya O, Glinka A, del Barco Barrantes I, Stannek P, Niehrs C, Wu W: RSpondin2 is a secreted activator of Wnt/beta-catenin signaling and is required for Xenopus myogenesis. Dev Cell 2004, 7:525-534.

40. Nam JS, Turcotte TJ, Smith PF, Choi S, Yoon JK: Mouse cristin/R-spondin family proteins are novel ligands for the Frizzled 8 and LRP6 receptors and activate beta-catenin-dependent gene expression. J Biol Chem 2006, 281:13247-13257.

41. Wei Q, Yokota C, Semenov MV, Doble B, Woodgett J, He X: R-spondin1 is a high affinity ligand for LRP6 and induces LRP6 phosphorylation and beta-catenin signaling. J Biol Chem 2007, 282:15903-15911.

42. Klauzinska M, Baljinnyam B, Raafat A, Rodriguez-Canales J, Strizzi L, Greer YE, Rubin JS, Callahan R: Rspo2/Int7 regulates invasiveness and tumorigenic properties of mammary epithelial cells. J Cell Physiol 1960, 227:1971.

43. Lowther W, Wiley K, Smith GH, Callahan R: A new common integration site, Int7, for the mouse mammary tumor virus in mouse mammary tumors identifies a gene whose product has furin-like and thrombospondin-like sequences. J Virol 2005, 79:10093-10096.

44. Theodorou V, Kimm MA, Boer M, Wessels L, Theelen W, Jonkers J, Hilkens J: MMTV insertional mutagenesis identifies genes, gene families and pathways involved in mammary cancer. Nat Genet 2007, 39:759-769.

45. Chadi S, Buscara L, Pechoux C, Costa J, Laubier J, Chaboissier MC, Pailhoux

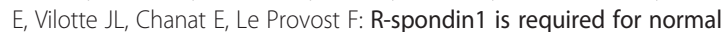
epithelial morphogenesis during mammary gland development. Biochem Biophys Res Commun 2009, 390:1040-1043.

46. Baljinnyam B, Klauzinska M, Saffo S, Callahan R, Rubin JS: Recombinant Rspondin2 and Wnt3a up- and down-regulate novel target genes in C57MG mouse mammary epithelial cells. PLoS One 2012, 7:29455.

47. Shackleton M, Vaillant F, Simpson KJ, Stingl J, Smyth GK, Asselin-Labat ML, Wu L, Lindeman GJ, Visvader JE: Generation of a functional mammary gland from a single stem cell. Nature 2006, 439:84-88.

48. Stingl J, Eirew P, Ricketson I, Shackleton M, Vaillant F, Choi D, Li HI, Eaves CJ: Purification and unique properties of mammary epithelial stem cells. Nature 2006, 439:993-997.

49. Liu BY, McDermott SP, Khwaja SS, Alexander CM: The transforming activity of Wnt effectors correlates with their ability to induce the accumulation of mammary progenitor cells. Proc Natl Acad Sci U S A 2004, 101:4158-4163.

50. Dontu G, Abdallah WM, Foley JM, Jackson KW, Clarke MF, Kawamura MJ, Wicha MS: In vitro propagation and transcriptional profiling of human mammary stem/progenitor cells. Genes Dev 2003, 17:1253-1270.

51. Liao MJ, Zhang CC, Zhou B, Zimonjic DB, Mani SA, Kaba M, Gifford A, Reinhardt F, Popescu NC, Guo W, et al: Enrichment of a population of mammary gland cells that form mammospheres and have in vivo repopulating activity. Cancer Res 2007, 67:8131-8138.

52. Mani SA, Guo W, Liao MJ, Eaton EN, Ayyanan A, Zhou AY, Brooks M, Reinhard F, Zhang CC, Shipitsin M, et al: The epithelial-mesenchymal transition generates cells with properties of stem cells. Cell 2008, 133:704-715.

53. Tao L, Roberts AL, Dunphy KA, Bigelow C, Yan H, Jerry DJ: Repression of mammary stem/progenitor cells by p53 is mediated by Notch and separable from apoptotic activity. Stem Cells, 29:119-127.

54. Stingl J, Caldas C: Molecular heterogeneity of breast carcinomas and the cancer stem cell hypothesis. Nat Rev Cancer 2007, 7:791-799.

55. Visvader JE: Keeping abreast of the mammary epithelial hierarchy and breast tumorigenesis. Genes Dev 2009, 23:2563-2577.

56. Chomczynski P, Sacchi N: Single-step method of RNA isolation by acid guanidinium thiocyanate-phenol-chloroform extraction. Anal Biochem 1987, 162:156-159.

doi:10.1186/1471-213X-12-25

Cite this article as: Gauger et al.: Loss of sfrp1 promotes ductal branching in the murine mammary gland. BMC Developmental Biology $201212: 25$. 